$12-2018$

\title{
Case Note: Case of Araya v. Nevsun Resources Ltd in the Canadian Courts
}

Jolene Hansell

University of Ottawa

Follow this and additional works at: https://digitalcommons.usf.edu/gsp

\section{Recommended Citation}

Hansell, Jolene (2018) "Case Note: Case of Araya v. Nevsun Resources Ltd in the Canadian Courts," Genocide Studies and Prevention: An International Journal: Vol. 12: Iss. 3: 177-181.

DOI:

https://doi.org/10.5038/1911-9933.12.3.1639

Available at: https://digitalcommons.usf.edu/gsp/vol12/iss3/16

This Case Study is brought to you for free and open access by the Open Access Journals at Digital Commons @ University of South Florida. It has been accepted for inclusion in Genocide Studies and Prevention: An International Journal by an authorized editor of Digital Commons @ University of South Florida. For more information, please contact digitalcommons@usf.edu. 


\title{
Case Note: Case of Araya v. Nevsun Resources Ltd. in the Canadian Courts
}

\author{
Jolene Hansell \\ University of Ottawa \\ Ottawa, Ontario, Canada
}

Canadian courts hear claims that violate Canada's domestic law. But what happens when a corporation violates fundamental human rights enshrined in customary international law, such as the prohibition against slavery, forced labor, and torture? Can the victims of these human rights violations bring a claim against the corporation in Canadian courts? Will Canadian courts hear this customary international law claim?

These questions are at issue in Araya $v$ Nevsun Resources Limited. If the answer is yes, this case could open the door to judicial remedies for victims of a corporation's customary international law violations.

\section{Case Background}

The Plaintiffs in this case are Eritrean refugees, Gize Yebeyo Araya, Kesete Tekle Fshazion, and Mihretab Yemane Tekle. They allege they were conscripted into the Eritrean National Service Program and forced to work in the Bisha gold mine. ${ }^{1}$ Nevsun Resources Limited is a British Columbia mining company that contracted with the Eritrean government to develop the Bisha gold mine. ${ }^{2}$ The Plaintiffs allege Nevsun is directly liable for the mine's forced labor practices.

Eritrea introduced compulsory military service in 1995, requiring every person under the age of 50 to serve in its National Service Program. ${ }^{3}$ This Program provides labor for various companies. ${ }^{4}$ By rule, the Program requires each Eritrean citizen to serve 18-months-six-months of military training and 12-months of military service. ${ }^{5}$ But, in reality, military conscripts are enlisted in the program indefinitely, serving an average of six and a half years. ${ }^{6}$

The Plaintiffs allege Nevsun used Eritrean National Service Program laborers to build infrastructure and mine facilities at the Bisha Gold Mine. They assert Nevsun forced them to work 12-hour days, six or seven days a week, fully exposed to the sun, in temperatures reaching 47 degrees Celsius. ${ }^{7}$ The Plaintiffs also claim they were tied up and beaten, received little food, and were housed in huts without beds or electricity. ${ }^{8}$ Human rights groups reported that laborers who attempted to flee these egregious working conditions were detained and tortured. ${ }^{9}$

The Plaintiffs brought a claim against Nevsun for damages under both Canadian domestic law and customary international law. ${ }^{10}$

Issue: Will a Canadian Court Hear a Claim for Damages under Customary International Law? The Plaintiffs allege their treatment as laborers for Nevsun violates customary international law prohibitions against forced labor; torture; slavery; and cruel, inhuman, and degrading treatment. ${ }^{11}$ Customary international law is a binding source of international law rooted in widespread and consistent state practice with opinio juris - a state's belief it has a legal obligation to conform with the widespread and consistent practice. ${ }^{12}$ Once a rule attains customary international law status,

\footnotetext{
${ }^{1}$ Araya v. Nevsun Resources Ltd., British Columbia Supreme Court, 2016 BCSC 1856, paras. 1-2.

${ }^{2}$ Ibid., paras. 1-2.

${ }^{3}$ CL London, "National Service in Eritrea: Miserable and Useless", The Economist, March 10, 2014, accessed November 14, 2018, https://www.economist.com/baobab/2014/03/10/miserable-and-useless.

${ }^{4}$ Araya v. Nevsun, BC Supreme Court, para. 28.

${ }^{5}$ Ibid., para. 4.

${ }^{6}$ London, National Service in Eritrea.

${ }^{7}$ Araya v. Nevsun, BC Supreme Court, para. 46.

${ }^{8}$ Ibid., paras. 44,46 .

${ }^{9}$ London, National Service in Eritrea.

${ }^{10}$ Araya v. Nevsun, BC Supreme Court, para. 42.

${ }^{11}$ Ibid., para. 43. The prohibitions are well-established customary international law norms. See James Crawford, ed., Brownlie's Principles of Public International Law (Oxford: Oxford University Press, 2012), 22.

${ }^{12}$ Crawford, Brownlie's Principles, 22; Statute of the International Court of Justice, June 26, 1945, Can TS 1945 No. 7, art. 38(1)

Jolene Hansell. "Case Note: Case of Araya v. Nevsun Resources Ltd. in the Canadian Courts." Genocide Studies and Prevention 12, 3(2018): 177-181. @2018 Genocide Studies and Prevention. 
it becomes universally binding with very few exceptions. ${ }^{13}$ Canadian law directly incorporates customary international law into its domestic legal framework. ${ }^{14}$ As such, Canadian courts can enforce customary international law without domestic legislation. ${ }^{15}$ The Plaintiffs rely on Canada's incorporation of customary international law as the basis for their claim to damages.

Nevsun challenged the Plaintiffs' ability to bring a claim for damages under customary international law by bringing a motion to strike the claim. A motion to strike is a preliminary, procedural tool that prevents courts from hearing claims that lack a reasonable prospect of success. ${ }^{16}$ Courts may grant a motion to strike if (1) the party cannot reasonably make the claim; (2) the claim is unnecessary, scandalous, frivolous, or vexatious; (3) the claim may prejudice, embarrass, or delay the fair trial of the case; or, (4) the claim abuses the court process. Importantly, a motion to strike safeguards judicial efficiency and integrity but does not prevent courts from recognizing a new cause of action. ${ }^{17}$

Because Nevsun argued the Plaintiffs could not bring a claim for damages under customary international law, Nevsun had to prove that the Plaintiffs customary international law claims had no reasonable likelihood of success. ${ }^{18}$

\section{Motion to Strike Dismissed: The Law is Not Settled and the Court is Reluctant to Reject a Novel Claim}

A court will only grant a motion to strike if it is plain and obvious that the claim has no reasonable prospect of success. ${ }^{19}$ Canadian courts apply this test generously, erring on the side of allowing a novel, but arguable, claim to proceed.$^{20}$ If a plaintiff's case has a chance to succeed, a court must give the plaintiff the opportunity to present its case. ${ }^{21}$ A novel claim alone is not sufficient grounds for the court to grant a motion to strike. ${ }^{22}$

Applying this test, the British Columbia Supreme Court found that the Plaintiffs' customary international law claim was not bound to fail because the law on this issue is not settled. ${ }^{23}$ The Court further held that expanding a customary international law cause of action would not radically transform Canadian law. ${ }^{24}$

Nevsun appealed the decision to the British Columbia Court of Appeal. ${ }^{25}$ The Court of Appeal remarked that the Plaintiffs would struggle to establish a claim for damages in customary international law. It nonetheless upheld the lower court's decision and denied Nevsun's motion to strike. ${ }^{26}$

On June 14, 2018, the Supreme Court of Canada granted Nevsun leave to appeal to Canada's highest court. ${ }^{27}$ If the Supreme Court of Canada upholds the British Columbia Court of Appeal's decision, judicial remedies could become available for victims of corporations' customary international law violations.

(b); North Sea Continental Shelf (Federal Republic of Germany v. Netherlands), International Court of Justice, Judgment,

February 20, 1969, [1969] I.C.J. Rep 3, 44; Military and Paramilitary Activities in and against Nicaragua (Nicaragua v. United

States), International Court of Justice Judgment on the Merits, June 27, 1986, [1987] I.C.J. Rep 14, para. 186.

${ }^{13}$ Araya v. Nevsun, BC Supreme Court, para. 434.

${ }^{14} R$ v. Hape, Supreme Court of Canada, 2007 SCC 26, [2007] 2 S.C.R. 292, para. 39.

${ }^{15}$ Louis LeBel, "A Common Law of the World? The Reception of Customary International Law in the Canadian Common Law," University of New Brunswick Law Journal 65 (2015), 3, 15.

${ }^{16} R$ v. Imperial Tobacco Canada Ltd., Supreme Court of Canada, 2011 SCC 42, [2011] 3 S.C.R. 45, paras. 19-20.

${ }^{17}$ Ibid., para. 21.

${ }^{18}$ Araya v. Nevsun, BC Supreme Court, paras. 424-425, 429.

${ }^{19}$ Ibid., para. 430.

${ }^{20}$ Ibid., paras. 432, 445.

${ }^{21}$ Ibid., para. 432, citing Hunt v. Carey Canada Inc, Supreme Court of Canada, [1990] 2 S.C.R. 952, 980.

${ }^{22}$ Ibid., para. 431.

${ }^{23}$ Ibid., paras. 427, 445, 485; Araya v. Nevsun Resources Ltd, British Columbia Court of Appeal, 2017 BCCA 401, para. 197.

${ }^{24}$ Araya v. Nevsun, BC Supreme Court, para. 442; Araya v. Nevsun, BC Court of Appeal, para. 196.

${ }^{25}$ Ibid., para. 197.

${ }^{26}$ Ibid., paras. 180, 196-197.

${ }^{27}$ Nevsun Resources Ltd v. Gize Yebeyo Araya, et al., Supreme Court of Canada, 2018 CanLII 53456 (CanLii). 
The Plaintiffs May Have Won the Battle but Not Necessarily the War

At this point, all the Plaintiffs have won is the ability to put their arguments before a court and have a judge consider them. In denying the Nevsun's motion to strike, neither the trial court nor the court of appeal considered the substantive arguments underlying the Plaintiffs' claim for damages. Instead, as a preliminary matter, the courts assumed the Plaintiffs' facts, as alleged, were true and only considered whether the Plaintiffs had a reasonable basis for the claim based on the current state of the law. ${ }^{28}$

If the Supreme Court of Canada permits the Plaintiffs' claim to proceed, it will allow the Plaintiffs to test the customary international law basis for their claim, provided the Plaintiffs can prove the wrongful conduct they allege.

To determine if the Plaintiffs can bring a claim for damages against a corporation for violating customary international law, the Court will need to answer two questions: (1) can customary international law provide an independent cause of action in Canadian domestic law, and (2) does customary international law bind corporations?

Can Customary International Law Norms Provide an Independent Cause of Action in Canadian Domestic Law?

The Plaintiffs will likely argue that Nevsun, a Canadian corporation, violated customary international law prohibitions against slavery and forced labor as incorporated into Canadian domestic law. But in doing so, the Plaintiffs are asking the Court to expand its traditional use of customary international law, which to date the Court has principally used to interpret Canadian domestic law.

The Supreme Court of Canada found that customary international norms are directly incorporated into Canadian law. ${ }^{29}$ But Canadian courts rarely rely on customary international law norms alone and instead primarily use customary international law to inform the content of Canada's domestic legal framework. ${ }^{30}$ For example, in Suresh v. Canada, the Supreme Court of Canada, in an unanimous decision, held that customary international law informs the principles of fundamental justice enshrined in the Canadian Charter of Rights and Freedoms. ${ }^{31}$ Customary international law therefore informs the interpretation of Canadian constitutional laws and legislation, as well as the development of the common law. ${ }^{32}$

The Plaintiffs' argument is novel, but not far-fetched: common law jurisdictions, including Canada, have used customary international law to develop private law obligations in commercial transactions, interjurisdictional marine transportation, and disputes relating to shipwrecks, hostages, and ransom bills. ${ }^{33}$ And Canadian courts have confirmed that civil causes of action can be based in customary international law if jurisdiction is otherwise established. ${ }^{34}$

The Court's decision on this question will either create a new cause of action based in customary international law or risk limiting judicial use of customary international law as an interpretative aid for existing Canadian law.

Does Customary International Law Bind Corporations?

Nevsun will likely argue that even if the Court finds the Plaintiffs can bring a claim based in

${ }^{28}$ Araya v. Nevsun, BC Supreme Court, paras. 428, 431; Araya v. Nevsun, BC Court of Appeal, para. 177.

${ }^{29} \mathrm{R} v$. Hape, para 39; LeBel, A Common Law of the World, 3, 15.

${ }^{30}$ Ruth Sullivan, Statutory Interpretation 3rd ed., (Toronto: Irwin Law, 2016), 311-313.

${ }^{31}$ Suresh v. Canada (Minister of Citizenship and Immigration), Supreme Court of Canada, 2002 SCC 1, [2002] 1 S.C.R. 3, paras. 43-48.

${ }^{32} R v$. Hape, para. 39.

${ }^{33}$ See, for example, William Blackstone, Commentaries on the Law of England, vol. 1 (Philadelphia: JB Lippincott Co, 1893), 273 (the discussion of how the customary international law lex mercatoria principle regulates commercial law is regulated); Balm v. 3512061 Canada Ltd., 2003 ABCA 98, 327 A.R. 149, paras. 10-11; Araya v. Nevsun, BC Supreme Court, para. 429.

${ }^{34}$ Bil'In (Village Council) v. Green Park International Inc, 2009 Q.C.C.S. 4151, [2009] RJQ 2579, para. 29; Mack v. Canada (AG) (2002), Ontario Court of Appeal, 60 O.R. (3d) 737, 165 O.A.C. 17; Abdelrazik v. Canada (Attorney General), Federal Court of Canada, [2010] F.C.J. No. 1028 (QL), para. 53. 
customary international law, the Plaintiffs cannot bring a customary international law claim against a corporation.

International law only binds subjects of international law: states and international organizations that have an international legal personality. ${ }^{35}$ While individuals are the primary subjects of domestic law, states are the primary subjects of international law because, at its core, international law (including customary international law) governs state conduct. ${ }^{36}$

But corporations act like states in many ways. They frequently conduct economic activity across international borders, contract with foreign states, and often have more resources and greater diplomatic power than some small states. ${ }^{37}$ This ability for corporations to act like states has led some scholars to argue international law binds corporate actions.$^{38}$ Corporations, however, do not have international legal personality. ${ }^{39} \mathrm{~A}$ private corporation's legal personality -including its rights, obligations, and capacities - are defined by its domestic legal system. ${ }^{40}$ Even multinational or transnational corporations are domestic, not international, legal entities; they are merely a series of corporations created under domestic law of several different states and linked together to form an international corporate network. ${ }^{41}$ And, notably, the Supreme Court of Canada has historically recognized that "a corporation can have no legal existence out of the boundaries of the sovereignty by which it is created." 42

Following this reasoning, Nevsun will likely argue it is not bound by customary international law - that as a British Columbia corporation, the Business Corporation Act solely governs its rights, obligations, and capacities. ${ }^{43}$ The intuitive argument, therefore, is that without a specific rule to bind corporations to customary international law, the Plaintiffs cannot bring a claim for damages based in customary international law. ${ }^{44}$

The Plaintiffs, however, will likely counter that even though Nevsun is not a subject of international law, the international community agrees that corporations must comply with human rights obligations.

International human rights treaties - the Universal Declaration of Human Rights, the International Convention on Civil and Political Rights, and the Convention against Torture and Other Cruel, Inhuman or Degrading Treatment or Punishment-indisputably prohibit slavery and forced labor. But Professor John Ruggie, the United Nations Special Representative for Business and Human Rights, concluded these treaties do not impose direct liability on corporations. ${ }^{45}$ Likewise, the United Nations Guiding Principles on Business and Human Rights are voluntary; they do not impose binding international obligations on corporations. ${ }^{46}$

Both the Plaintiffs and Nevsun relied on US court decisions to support their arguments. But the United States Supreme Court has since clarified the law. In Jenser v. Arab Bank, the US Supreme

\footnotetext{
${ }^{35}$ John H. Currie, Public International Law, 2nd ed. (Toronto: Irwin Law, 2008), 20-21.

${ }^{36}$ Crawford, Brownlie's Principles, 115; Currie, Public International Law, 21.

${ }^{37}$ Crawford, Brownlie's Principles, 121-122.

${ }^{38}$ See Ignaz Seidl-Hohenveldern, Corporations In and Under International Law (Cambridge: Cambridge University Research Center for International Law, 1987).

${ }^{39}$ Crawford, Brownlie's Principles, 122.

${ }^{40}$ Currie, Public International Law, 75.

${ }^{41}$ Ibid., 76.

${ }^{42}$ Canadian Pacific Railway Co. v. The Western Union Telegraph Co., Supreme Court of Canada, (1889) 17 S.C.R. 151, 1889 CanLlI 5325 (SCC).

${ }^{43}$ Araya v. Nevsun Resources Ltd, British Columbia Supreme Court, Chambers Brief of the Defendant Nevsun Resources Ltd. Application to Strike Plaintiffs' Customary International Law Claims as Disclosing No Reasonable Claim, No. S-148932, para. 26.

${ }^{44}$ Araya v. Nevsun Resources Ltd, Chambers Brief of the Defendant Nevsun Resources Ltd. Application to Strike Plaintiffs' Customary International Law Claims, para. 28.

${ }^{45}$ United Nations Special Representative for Business and Human Rights, Report of the Special Representative of the SecretaryGeneral on the Issue of Human Rights and Transnational Corporations and other Business Enterprises, February 9, 2007, UN Doc. A/HRC/4/35, para. 44.

${ }^{46} \mathrm{~J}$. Anthony VanDuzer, Penelope Simons, and Graham Mayeda, Integrating Sustainable Development into International Investment Agreements (London: Commonwealth Secretariat, 2013), 296.
} 
Court found that while corporations may be liable in some circumstances, there is no "specific, universal, and obligatory norm of corporate liability." ${ }^{\prime 7}$ The Canadian government appears to take the same position. In fact, Canada objected to the US district court's jurisdiction in Presbyterian Church of Sudan v. Talisman Energy, an earlier case brought against a Canadian corporation for allegedly aiding and abetting the Sudanese government's human rights abuses. ${ }^{48}$

The Supreme Court of Canada's ruling on whether customary international law binds corporations raises two possible problems. First, while unlikely, if the Court finds that corporations like Nevsun are subjects of international law, immunity could prevent the claim from proceeding. International law affords international organizations with international legal personality state privileges and immunities, including immunity from civil proceedings in foreign states where the organization conducts activities. ${ }^{49}$ If Nevsun were an international legal subject, it could attract immunity from foreign civil proceedings in certain circumstances. On the facts of this case, the problem is moot because Nevsun is a Canadian corporation and the Plaintiffs brought the case in Canada. But had the Plaintiffs brought the case in Eritrea, and Eritrea's courts recognized customary international law as binding on corporations, Nevsun could argue that its immunity as a foreign international legal subject bars the Plaintiff's case.

Second, if the Court finds that customary international law provides a cause of action but that it does not bind corporations, the Court will render the cause of action meaningless. For the Plaintiff to bring a claim based in customary international law against Nevsun, Nevsun must have binding obligations under customary international law. So even though the customary international law cause of action exists, this subsequent procedural bar could prevent the Plaintiff from bringing the claim.

\section{Conclusion}

The Supreme Court's decision could very well open the door to a new customary international law action in Canada. If the Court denies Nevsun's appeal and upholds the lower courts' decision, it affords the Plaintiffs the opportunity to prove the legal basis for their customary international law claim. Proving this claim will not be easy but, if the Plaintiffs succeed, Canadian courts will, for the first time, provide judicial remedies for victims of a corporation's customary international law violations.

\footnotetext{
${ }^{47}$ Jesner et al., v. Arab Bank PLC, United States Supreme Court, No. 16-499, April 24, 2018, 17 (the plaintiffs alleged the Arab Bank, a Jordanian corporation, financed terrorist attacks that injured the themselves or their family members. To arrive at its decision, the US Supreme Court relied heavily on the Alien Tort Statute's purpose to promote harmony in international relations and found that foreign defendants create unique problems in foreign relations. The US Supreme Court did not comment on the Plaintiff's ability to bring the case against an American corporation).

${ }^{48}$ Doe v. Exxon Mobil Corp., 654 F. 3d 11, 77-78 (CADC 2011) (Kavanaugh, J., dissenting in part).

${ }^{49}$ Crawford, Brownlie's Principles, 171, 175.
} 